\title{
Effectiveness of Gravity Goods Ropeways in market participation of smallholder farmers in uplands
}

\author{
Diwakak KC ${ }^{1}$ Tek Maraseni ${ }^{2}$ Chubamenla Jamir ${ }^{3}$ Ritendra Thapa Magar ${ }^{4}$ Florencia Tuladhar $^{5}$
}

Abstract: Isolated from the market due to harsh terrain, low farm productivity and poor road connectivity, the majority of farmers in the upland region of Nepal practice subsistence farming characterized by abject poverty. This study investigates whether Gravity Goods Ropeway (GGR) improves market participation and livelihood of smallholder farmers in uplands. 113 households' surveys, 6 focus group discussions, and 39 key informant interviews were conducted in 3 upland villages of Nepal. The before-after analysis was applied to examine the impact of GGR.

With reduced average travel time to end market by $57 \%(p<0.05)$, the farmers were able to transport high-quality products directly to small-scale (retailers and consumer) and large-scale (wholesaler) buyers eliminating the role of intermediaries. Additionally, GGR significantly reduced transportation cost by $43 \%$ ( $p<0.05$ ), post-harvest loss by $39 \%$ ( $<<0.05)$, and time for information search enabling farmers to dictate and capture higher share in final selling price.

The average quantity of high-value crops (vegetable) supplied to the output market (84\%), farm income (84\%) and food expenditure $(31 \%)$ increased significantly $(\mathrm{p}<0.05)$ fulfilling the food needs of upland farmers for the entire year through the increased purchase of rice, pulses and processed food. Unlike the output market, the farmers' participation in purchasing fertilizer, seeds and other equipment in the input market remained low as they continued to rely on traditional methods because of low cost and local applicability. Therefore, GGR could be one of the suitable technology for upland of Nepal. However, further research is required focusing on the financial (cost/benefit) aspect, a possibility of improving the technology and operation mechanism which will genuinely justify that GGR is a suitable technology in mountain regions of Nepal and elsewhere with similar topographic conditions.

\footnotetext{
Corresponding Author: Diwakar KC diwakarkc.88@gmail.com

${ }^{1}$ Department of Marketing, Griffith University, Brisbane, Australia

${ }^{2}$ Institute of Agriculture and the Environment, University of Southern Queensland, Toowoomba, Queensland Australia

${ }^{3}$ Department of Energy and Environment, TERI School of Advanced Studies, New Delhi, India

${ }^{4}$ Department of International Studies, University of Oregon, Eugene, USA

${ }^{5}$ Department of Civil and Geomatics Engineering, Kathmandu University, Dhulikhel, Nepal
} 
Keywords: Gravity Goods Ropeways; Smallholder farmers; market participation; travel time

\section{Introduction}

Poverty alleviation and food security have been the priority since last few decades including recently instituted sustainable development goals (SDGs). Particularly, SDG 1 "end poverty in all forms everywhere" and SDG 2 "end hunger, achieve food security and improved nutrition and promote sustainable agriculture" are dealing these issues (United Nations 2016). Nevertheless, there are 767 million people (10\%) primarily associated with small landholding farming and living under the poverty line of less than US\$ 1.90 a day (FAO 2017; Wickramasinghe and Weinberger 2013; World Bank 2016). Out of 570 million farms managing the majority of the world's agricultural land, $80 \%$ comprise of small farms of less than 2 ha often living in remote locations mostly isolated from the market and other socio-economic opportunities (Lowder et al. 2016). Mainly, farmers residing in uplands and mountain regions are more vulnerable and likely to face multiple deprivations due to inaccessibility, fragility, marginality, and diversity (Jin et al. 2006; Mohanty et al. 2018). Up to 90\% of farmers residing in highlands are poor whose livelihood could be improved through context-specific strategies and interventions (Hunzai et al. 2011; Papola 2002).

Nepal is a small mountainous country in South Asia where topography is the most significant hindrance for transport infrastructure prohibiting more than $50 \%$ of the farmers to market (Baral 2012; Devkota et al. 2012), which is one of the primary basis to earn income and encouraging factor to engage in farming (Arias et al. 2013; Jordaan et al. 2014; Markelova and Mwangi 2010). Hence, the majority of farmers are forced to cultivate food crops to derive subsistence (Basnett et al. 2014; Maraseni et al. 2006). The situation is even worse as more than $80 \%$ farmers are smallholders with average land holding size less than 0.5 hectares unable to sustain for a whole year with their agriculture produce (Dhakal et al. 2012; Karki and Karki 2011). Even if farmers generate the marketable surplus, transportation, and its associated transaction costs are so high, it becomes impossible for them to participate in markets getting trapped inside a vicious cycle of poverty (ADB 2014; Basnett et al. 2014; Maraseni et al. 2006). 
As noted, globally, only about $10 \%$ people are under poverty line but in Nepal, this value is over 25\%, and in uphill, this proportion is very high, over 40\% (ADB, 2017).

The Government of Nepal has been prioritizing roadways for the development of transport infrastructure since the inception of the first five-year development plan in 1956 (NPC 2016). Since road construction is expensive in uplands, foot trails and mule tracks remain the only available option to transport goods physically (KC 2009; Magar 2016). It stretches the duration of travel, and isolates farmers from the market, unlikely to generate any economic improvement (Hong et al. 2011; Neven et al. 2009). In this context, Gravity Good Ropeways (GGR) emerge as alternative and complementary means for mountain transportation. First introduced by Practical Action (UK based international Development Organization with its office in Nepal) a few years ago, GGR has helped to connect few mountain villages with the market at the lower installation, operation, and maintenance cost than roads. However, it is still not the popular technology - only 22 GGRs have been installed so far (Practical Action Nepal, 2016). Globally also, the use of GGR is limited to a few mountain areas in Switzerland, India, and Bangladesh (DOLIDAR 2010). It is mainly due to less attention from national governments, development organizations, and academia. Besides few newspaper articles and project reports, there is no comprehensive research demonstrating the actual impact of GGR and the role it could play to improve the livelihood of mountain people. Therefore, this study fills this gap and aims to identify whether GGR is a suitable technology to enhance the livelihood of smallholder farmers in uplands and mountainous area. By undertaking the case studies of three operational GGR sites in high hills of Nepal, this research investigates how GGR affect price negotiation process and farmer's engagement in input and output market.

The rest of this paper has the following organization. The next section presents a brief overview of GGR system and the technology behind it. "Methodology" section explains the data collection and analysis methods. The findings and analysis are described in "Results and Discussion" section. The conclusion section provides the summary and limitation of the research. 


\section{Technology behind GGR}

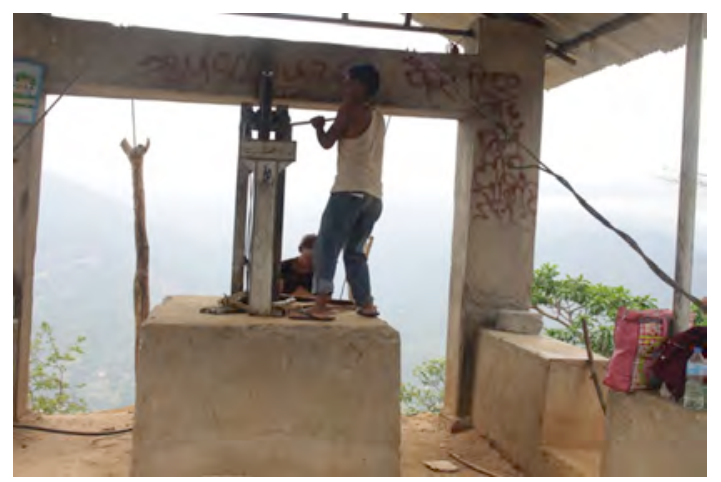

1a. GGR operator about to start the GGR at uphill station

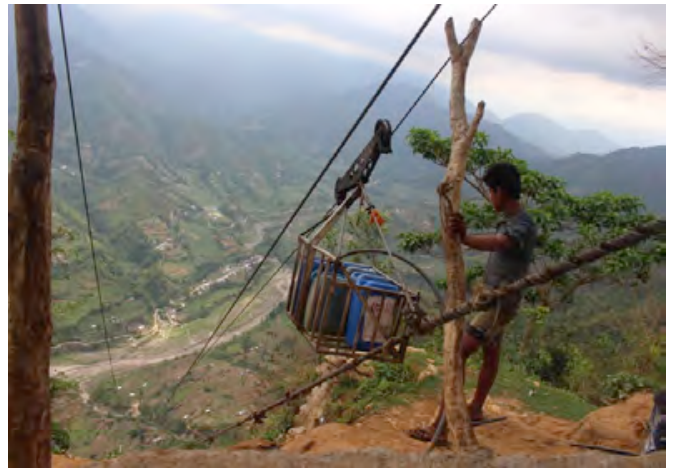

1b. Goods loaded in first trolley in the uphill station being transported to bottom station

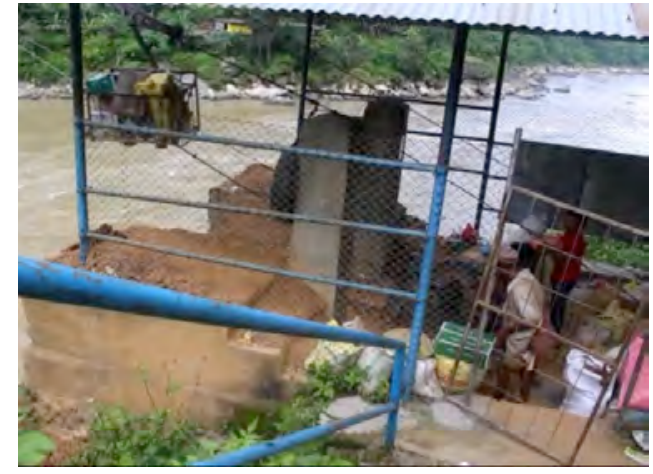

1c. Goods in second trolley at downhill station moving simultaneously to uphill station

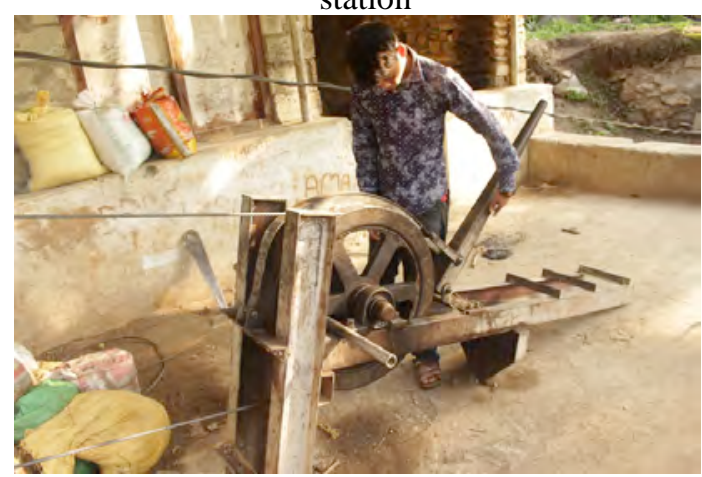

1d. Operator applying brake at down hill station to stop the movement of trolleys

Fig 1 Major component of GGR 
GGR is non-motorized means of transportation that uses the earth's gravity to transport goods. They are short- haul ropeways created for the steepest section of the hills working solely on gravitational force without any other external power. There are two stations on the uphill and downhill, each with the speed control pulley and brake system as shown in Fig. 1a and 1d connected by a wire on which trolley slides up and down. It works two ways- while one carrier/trolley transport agricultural produce or goods from uphill (as shown in Fig. 1b), its weight pulls the other carrier at the bottom station up the hill (as shown in Fig. 1c). However, the carrier going uphill should only have one-third of the weight of the goods coming downhill. For instance: if the weight of products coming downhill is $90 \mathrm{~kg}$, products going uphill must not exceed 30kg (DoLIDAR, 2010).

\section{Methodology}

\section{Study area}

Three GGR sites in Ghairang, Chimkeshwori, and Hiklung villages were selected (Please refer to Table 1 and Fig 2 for the detail information on the location of study sites) to investigate whether GGR had any impact on market access of smallholder farmers. Each research site was carefully selected to ensure that they would proportionally represent all the 22 GGR sites of Nepal. Therefore, three different GGR sites inhabited by three major indigenous tribes Gurung, Gole and Chepang were selected in terms of the geographical distance to nearby market centers. The brief description of each site is summarized in Table 1: 


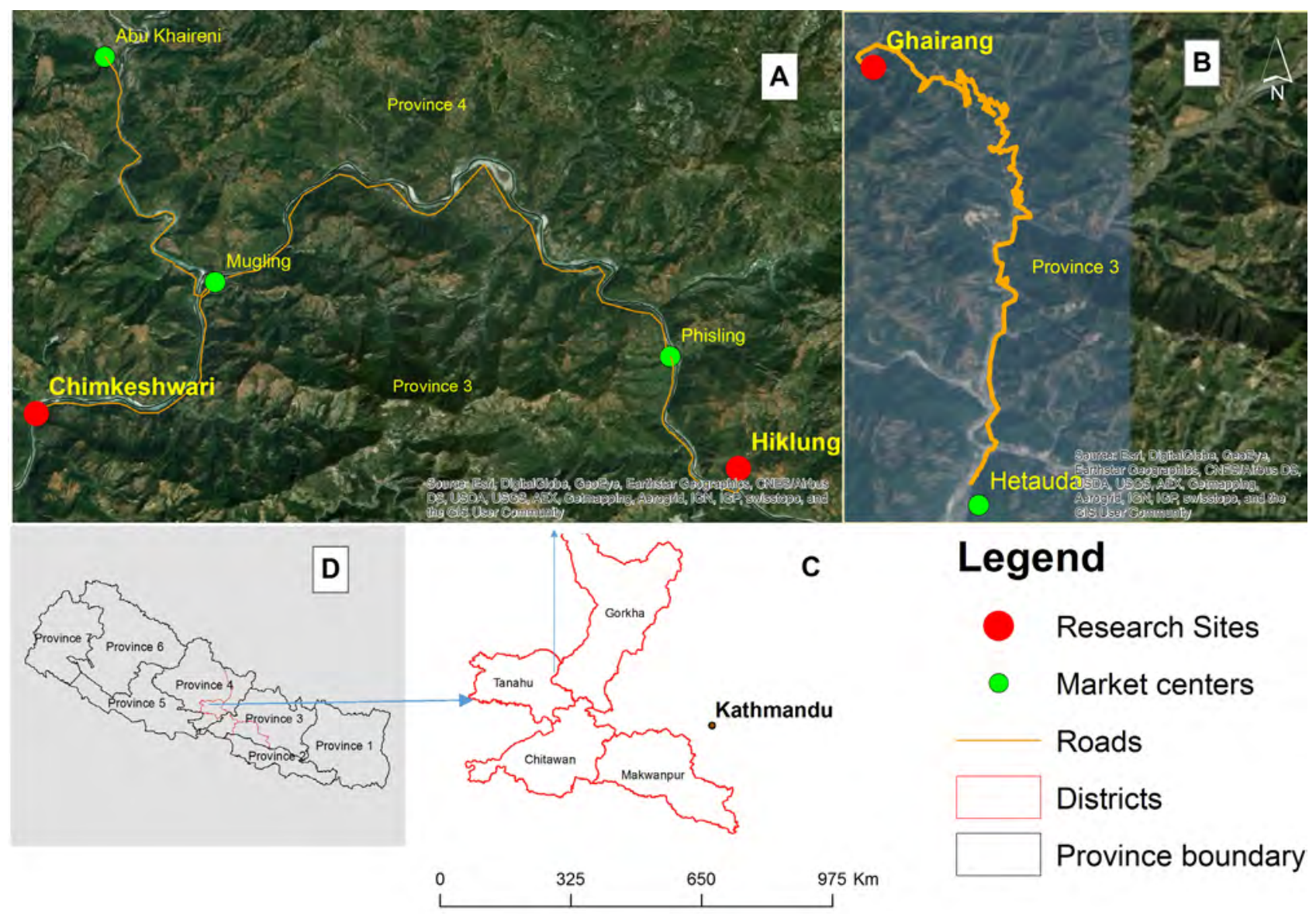

Fig 2 Study area and their market center

\section{Data collection}

Access to and participation in the market for smallholder farmers involved numerous social processes (interaction with multiple stakeholders, price negotiation, crop consolidation) beside transportation and territorial access to the market. Mix method is ideal for such research examining the quantifiable impacts and the social process involved (Baker 2000). Therefore, this research used both quantitative and qualitative method for data collection and analysis. Since GGRs were already installed, the field work and household surveys were carried out only once using the recall method to collect data reflecting before and after scenario of GGR. All selected GGR sites were constructed just 2-5 years ago which helped respondents to recollect past events easily and quickly. Moreover, following things were carried out to minimize recall bias and 
collect accurate information (1) interviews were conducted for the longer time allowing families to sit together and come to consensus; (2) follow-up questions were asked restructuring in various ways to clarify doubts; and (3) information was triangulated with other key stakeholders.

The purposive random sampling was used to identify samples for household surveys to investigate how farmers participated in the market after installation of GGR. Since each village was homogenous (inhabited by one dominant tribe), 30\% were taken as samples. Altogether 113 smallholder farmers were interviewed for the household survey (Please refer to Table 1 for details regarding the sample and the total households in each village). Moreover, six focus group discussions (2 FGDs in each village) were conducted to have an in-depth understanding of how the price negotiation process and market participation affected by GGR. Subsequently, snowball method was utilized to identify other vital stakeholders comprising of 11 local politicians, 4 GGR operator, 13 GGR management committee representatives, 4 transporters, 7 wholesalers for key-informant interviews to examine the influence of farmers in the price negotiation process.

Table 1 Demographic, geographic and economic characteristics of study sites

\begin{tabular}{|c|c|c|c|c|}
\hline Study sites & $\begin{array}{l}\text { Demographic } \\
\text { Characteristics }\end{array}$ & Location & Major Crops & $\begin{array}{l}\text { Market Centers } \\
\text { (Distance from GGR } \\
\text { bottom station) }\end{array}$ \\
\hline Ghairang, & $\begin{array}{l}\text { Total HHs*: } 92 \\
\text { Sampled HHs: } 36 \\
\text { Tribe: Gole }\end{array}$ & $\begin{array}{l}\text { District: Makwanpur } \\
\text { Province: } 3 \\
\text { Distance*: } 90 \mathrm{~km} \\
\text { Elevation: } 850 \mathrm{~m} \\
\text { asl*** }\end{array}$ & $\begin{array}{l}\text { Food crops (for } \\
\text { household } \\
\text { consumption): }\end{array}$ & Hetauda (32 km) \\
\hline $\begin{array}{l}\text { Chimkeshwori, } \\
\text { Tanahun } \\
\text { District }\end{array}$ & $\begin{array}{l}\text { Total HHs: } 95 \\
\text { Sampled HHs: } 42 \\
\text { Tribe: Gurung }\end{array}$ & $\begin{array}{l}\text { District: Tanahun } \\
\text { Province: } 4 \\
\text { Distance: } 120 \mathrm{~km} \\
\text { Elevation: } 1100 \mathrm{~m} \text { asl }\end{array}$ & $\begin{array}{l}\text { maize, millet } \\
\text { Cash crops (for } \\
\text { selling in the }\end{array}$ & $\begin{array}{l}\text { Mugling (18.2 km) } \\
\text { Khaireni (21.7 km) }\end{array}$ \\
\hline $\begin{array}{l}\text { Hiklung, } \\
\text { Gorkha } \\
\text { District }\end{array}$ & $\begin{array}{l}\text { Total HHs: } 88 \\
\text { Sampled HHs: } 35 \\
\text { Tribe: Chepang }\end{array}$ & $\begin{array}{l}\text { District: Gorkha } \\
\text { Province: } 4 \\
\text { Distance: } 95 \mathrm{~km} \\
\text { Elevation: } 800 \mathrm{~m} \text { asl }\end{array}$ & $\begin{array}{l}\text { market): } \\
\text { Vegetables }\end{array}$ & $\begin{array}{l}\text { Mugling (15.1 km) } \\
\text { Phisling (4.4 km) }\end{array}$ \\
\hline
\end{tabular}

Source: Household survey and key informant survey, 2016

Note: * Distance of study sites from Country's Capital Kathmandu, ${ }^{* *} \mathrm{HH}=$ households, $* * * a s l=$ above mean sea level,

Like many other studies on road access and market participation(Årethun and Bhatta 2012; Dorosh et al. 2010; Kiprono and Matsumoto 2014), this research also investigated how GGR affected the travel time and transaction cost followed by its influence over price 
determination process and participation in the input and output market. Agricultural production, farm income, food expenditure, and farm input purchase, were used to measure the level of involvement in input and output market (Årethun and Bhatta 2012; Dorosh et al. 2010).

\section{Data analysis}

The before-after analysis is one of the useful tools to evaluate the impact of agriculture projects (Leeuw and Vaessen 2009; Suvedi and Vander Stoep 2016). Hence, this paper analyzed the quantitative data comparing before-after descriptive statistics. Ratio, percentage, and means were calculated to quantify the change in impacts due to GGR. Furthermore, paired two-sample t-tests were carried out to test the significance. Likewise, the qualitative data were analyzed using before-after content analysis techniques (Altheide 1987; Morgan 1993) consisting of central themes around market distance, market channel, transaction cost, and price negotiation process. Microsoft Excel and R were used for the data entry and analysis.

\section{Results and discussion}

\section{Transportation and price negotiation}

Farmers residing in high hills with poor road connectivity usually have to compromise with the lower price and profit due to hardship in travel and higher transport and transaction cost. It also forces them to rely on other market intermediaries such as middlemen or traders who accumulate and transport agricultural products and dictate price capturing a significant share of profit in the process (Fafchamps and Hill 2005). The installation of GGR in high hills defunct such traditional way of dependence upon traders and transporter by decentralizing negotiation power and redistributing profit to the farmers through the quickest connection and reduced transaction cost.

\section{Fastest connection to the market}

The use of GGR has significantly reduced the transport time to the nearest market centers (please refer to Table 1 and 2 for the location and distance of the nearest market for each village). In the past, it used to take more than 3 hours (average of travel time in three study sites) for agriculture 
produce grown at the uphill village to reach the nearest road head. Farmers would generally transport agriculture products physically by carrying either themselves or hiring a porter. Now, it takes less than 3 minutes in average to reach the road head (bottom station of all GGRs touches road-heads that are part of either national highways or rural road) from the uphill with the help of GGR as presented in Table 2. Moreover, farmers could even transport their produce during the rainy season which was not possible before GGR as foot trails used to be slippery and risky due to frequent landslides and rainfall. As a consequence, agriculture products now reach the final market center all year round from the road head in a couple of hours from the uphill village as shown in Table 2.

Table 2 Average time to reach final market in three study sites from top hill villages

\begin{tabular}{|c|c|c|c|c|}
\hline Description/Location & 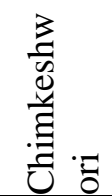 & 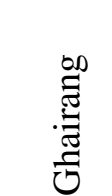 & 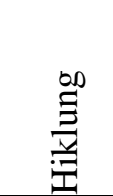 & $\begin{array}{l}\text { Average of average } \\
\text { transport time in } \\
\text { three study sites }\end{array}$ \\
\hline $\begin{array}{l}\text { Average time taken by farmer to transport good from } \\
\text { house to GGR top hill station (minutes) [A] }\end{array}$ & 23 & 16 & 16 & 18 \\
\hline $\begin{array}{l}\text { Average time taken by GGR to transport good from } \\
\text { top hill to bottom hill station at road head (minutes) } \\
\text { [B] }\end{array}$ & 3 & 3 & 2 & 2 \\
\hline $\begin{array}{l}\text { Average time to transport good from Road Head to } \\
\text { Nearest Market by public vehicle (minutes) [C] }\end{array}$ & 143 & 150 & 21 & 107 \\
\hline $\begin{array}{l}\text { Average of total time to reach final market using GGR } \\
\text { (minutes) }[\mathrm{X}=\mathrm{A}+\mathrm{B}+\mathrm{C}]\end{array}$ & 169 & 168 & 39 & 128 \\
\hline $\begin{array}{l}\text { Average time taken to transport good from farm to } \\
\text { road head hiring porter or carrying themselves [D] }\end{array}$ & 210 & 201 & 151 & 189 \\
\hline $\begin{array}{l}\text { Average of total time to reach good from houses to } \\
\text { final market without GGR }[Y=C+D]\end{array}$ & 353 & 351 & 172 & 296 \\
\hline $\begin{array}{l}\text { Change in average travel time before and after GGR } \\
\text { [X-Y] }\end{array}$ & $-52 \%$ & $-52 \%$ & $-77 \%$ & $-57 \%$ \\
\hline
\end{tabular}

Source: Household survey, and focus group discussion, 2016

With significant shrinkage in average travel time by 57\%, GGR has also provided the unique opportunity of anytime transportation of agriculture product to the market regardless of their lower volume of the farm quantity as shown in Table 2. More than $90 \%$ smallholder farmers reported that they have been able to transport and sell quantity as small as $5 \mathrm{~kg}$ consolidating with other household products (fuelwood, water, etc.) or with other farmers' 
agriculture goods as GGR could be operated with less than $50 \mathrm{~kg}$ weight from the uphill. It was impossible prior GGR as farmers had to wait for few days to few weeks to accumulate sizable quantity (70-100 kg) of agriculture product below which the transaction would be unprofitable due to higher transaction cost and longer transportation time to the market. Even if they transported the farm product, they failed to obtain higher prices as the occasional supply of 70$100 \mathrm{~kg}$ of product was not sufficient to fulfill the stable quantity required by large wholesaler on a daily basis and exceed the volume required by small retailers who would buy 40-50 $\mathrm{kg}$ of various product on a daily basis. Hence, they used to rely on traders or intermediaries who would accumulate and transport a sizable quantity from multiple farmers to sell in the market.

It is usually the problem faced by the majority of smallholder farmers globally as they cannot generate stable marketable surpluses to meet stringent requirements of the consistent supply of good quality produce necessary to fetch appropriate price (Barrett 2008; Ferris et al. 2014; Jordaan et al. 2014). Jayne et al., (2010) also discovered in Eastern and Southern Africa, the probability of being a net seller and exercising market power to fetch higher price increased significantly with land holdings of 4 ha and above. The situation is even worse in rural areas with poor road connectivity as households have to forcefully sell their produce comparatively at the lower price to safeguard their future transaction with the trader without whom their connection with the buyers would evaporate. In Uganda, similar practice persisted in the rural area without road infrastructure. Farmers purchased transport services indirectly by accepting lower prices for their outputs by selling to traders at the farm gate and intermediate points (Fafchamps and Hill 2005; Jacoby and Minten 2009).

The use of GGR in study sites has reduced their dependency on traders or intermediaries. Since the small quantity of the high-quality agricultural produce reaches the final market instantly, the farmers have been able to create a direct connection with the range of buyers depending upon the size of their agriculture produce. More than 90\% farmers during FGD reported that they have been selling their crops directly to consumers, (if quantity $<5 \mathrm{~kg}$ ), retailers (if quantity $>5 \mathrm{~kg}$ ) or wholesaler (if quantity $>20 \mathrm{~kg}$ ). Interestingly, farmers have organized themselves into the groups to accumulate and sell the product to large-scale buyers (who purchase more than $50 \mathrm{Kg}$ of crops per day). Especially during April to September, per day harvest of vegetable is higher in uplands (more than $20 \mathrm{~kg}$ per farmer per day) and farmers work 
in several informal groups to aggregate and transport crop to large-scale buyers. This mechanism has reduced the necessity of each farmer for traveling down to the market to sell their products resulting in saving of time and transportation cost. For instance, in study sites at Hiklung and Chimkeshwori, market management committee has been formed which becomes active mostly for the period between April to September to supply large quantity of vegetables (more than 50 $\mathrm{kg}$ ) to large-scale buyers. As a result, individual farmers don't need to travel to market for each transaction which has saved time to work in the field as well as transportation cost to capture a higher share of profit.

Consequently, the price negotiation process has altered in favor of farmers. As the presence of alternative buyers increases the efficiency of the marketing system through prevention of monopolistic tendencies (Ahmed and Hossain 1990; Anderson and Masters 2009; Bwalya et al. 2013; Minten 1999), farmers from the study area have gained immense market power to decide their farm gate price and profit because of their ability to deal with range of end buyers directly. Smallholder farmers in other parts of the upland region of Nepal also had similar experiences of exercising higher market power and fetching larger profit share after dealing directly with end buyers as opposed to selling through traders, transporter and collectors (Pokhrel 2010; Pokhrel and Thapa 2007).

\section{Reduced transaction cost}

Transaction costs can significantly affect decisions on whether or not to participate in the market (Cuevas 2014). Farther the farms from the market, higher the transaction costs raising the price paid by buyers and lowering the price received by sellers of a good, creating a situation unprofitable to either sell or buy (Key et al. 2000). It clarifies why farmers in a remote and isolated village choose to produce for household subsistence and avoid to involve in market opportunities (Janvry et al. 1991; Thünen et al. 1966). Notably, for smallholder farmers, the transaction cost is considered higher primarily because of their smaller volume of production and remoteness to the market raising per unit cost of transport and storage negatively affecting their participation in the market (Cuevas 2014; Ferris et al. 2014; Maraseni et al. 2006; Pingali et al. 2005). 
The use of GGR in the study sites has reduced the transaction cost related to handling, transportation, storage, and search for price information helping smallholder farmers to participate in the market. The average cost to transport one $\mathrm{kg}$ of vegetable from the top hill to the nearest market and vice-versa has reduced significantly by $43 \%(\mathrm{p}<0.05)$ as shown in Table 3. The similar result was also found in Bangladesh, where the reduction in transportation cost was $40 \%$ after the development of road infrastructure (Khandker et al. 2009). Likewise, the need to store agriculture product has almost evaporated in study sites as farmers could transport smaller volume of their produce directly from the farm to the market right after the harvest retaining the quality and freshness. Moreover, anytime quick transport to market without any transit has lowered down the average postharvest loss (quantity and quality) by $39 \%(\mathrm{p}<0.05)$ while transporting every $100 \mathrm{~kg}$ of goods as presented in Table 3. As a result, the competitiveness of the product has enhanced putting the farmers in an upper hand during the negotiation process.

Table 3 Average transport cost and postharvest quantity and quality loss before and after GGR

\begin{tabular}{|c|c|c|c|c|c|}
\hline Description & Unit & $\begin{array}{l}\text { Before } \\
\text { GGR }\end{array}$ & $\begin{array}{l}\text { After } \\
\text { GGR }\end{array}$ & $\begin{array}{l}\text { Change in } \\
\text { average cost }\end{array}$ & $\begin{array}{l}\text { t-value } \\
\text { (p-value) }\end{array}$ \\
\hline $\begin{array}{l}\text { Per unit average transport cost from top } \\
\text { hill to road head (NPR/Kg) [A] }\end{array}$ & NPR/Kg/HH & 2.50 & 1 & $-60 \%$ & $\begin{array}{l}8.23 * * \\
(0.000)\end{array}$ \\
\hline $\begin{array}{l}\text { Per unit average transport cost from road } \\
\text { head to nearest market (NPR/Kg) [B] }\end{array}$ & NPR/Kg/HH & 1 & 1 & $0 \%$ & \\
\hline $\begin{array}{l}\text { Total per unit average cost to transport } \\
\text { from uphill to final market (NPR/Kg) } \\
{[\mathrm{A}+\mathrm{B}]}\end{array}$ & NPR/kg/HH & 3.50 & 2.00 & $-43 \%$ & $\begin{array}{l}8.23^{* *} \\
(0.000)\end{array}$ \\
\hline $\begin{array}{l}\text { Average postharvest quantity loss while } \\
\text { transporting from uphill to final market } \\
\text { (in every } 100 \mathrm{Kg} \text { ) X }\end{array}$ & $\mathrm{Kg} / \mathrm{HH}$ & 6.31 & 3.88 & $-39 \%$ & $\begin{array}{l}8.598^{* *} \\
(0.000)\end{array}$ \\
\hline $\begin{array}{l}\text { Average postharvest quality loss while } \\
\text { transporting from top hill to final market } \\
\text { (in every } 100 \mathrm{~kg} \text { ) [Y] }\end{array}$ & $\mathrm{Kg} / \mathrm{HH}$ & 3.70 & 2.23 & $-40 \%$ & $\begin{array}{l}8.95^{* *} \\
(0.000)\end{array}$ \\
\hline $\begin{array}{l}\text { Total quantity and quality loss (in every } \\
100 \mathrm{~kg})[\mathrm{X}+\mathrm{Y}]\end{array}$ & $\mathrm{Kg} / \mathrm{HH}$ & 10.01 & 6.11 & $-39 \%$ & $\begin{array}{l}11.05^{* *} \\
(0.000)\end{array}$ \\
\hline
\end{tabular}

Source: Focus group discussion and key informant interview (1 USD = NPR 100)

**: Statistically significant at 5\%

Direct territorial and physical access to market centers through GGR have helped farmers to create the database of the potential buyers. Moreover, the extensive uses of phone and radio services have made it easy to acquire daily market price information tracking down the market centers/buyers offering the appropriate price and higher profit. It further prevented the distortion 
of the market price reducing information asymmetry between buyers and sellers reducing the magnitude of transaction cost (Årethun and Bhatta 2012; Bwalya et al. 2013). As a result, farmers acquired better negotiation power to dictate the price for their agricultural produce. In Hiklung and Chimkeshwori, farmers have established a good connection with the myriad of buyers from Phisling, Mugling and Khaireni markets enabling them to decide selling price with the buyers over the phone. In Ethiopia and Zambia, farmers were trading with grain brokers because of higher transaction cost associated with the longer time required searching for information on markets and appropriate price due to poor road connectivity with the market and other buyers (Bwalya et al. 2013; Gabre-Madhin 2001; Pingali et al. 2005).

\section{Participation in market}

Access to and participation in the market means that producer can reliably sell more products at higher prices and buy farm inputs at lower prices which gradually enhance their income and capacity to deal with risks and shocks (IFAD 2011). The households in all three-study sites increased participation in various markets related to farm products, food, manufactured commodities, fertilizer, and other agricultural inputs. Especially, after having a higher stake in the price determination process, the involvement of farmers in the output market has upsurge showing a positive impact on income and production of crops. Since most of the households were deficit food producers, they also participated in food markets as net buyers.

\section{Involvement in the output market}

With the better transportation network after installation of GGR, all 113 households have confirmed that they have increased selling their products to the output market. A significant increase of 35\% $(\mathrm{p}<0.05)$ in average annual farm production from $2082 \mathrm{~kg}$ to $2815 \mathrm{~kg}$ depicted the rise in the volume of marketable product (Table 4). The research conducting a cross-country regression in Sub Sahara Africa has also found substantial growth in production of maize and milk due to ease of access through rural road extension resulting in the participation of farmers in the output market (Dorosh et al. 2010; Kiprono and Matsumoto 2014). Interestingly, in all three study sites, per household average annual quantity of vegetable supplied to the market has increased significantly by $84 \%(\mathrm{p}<0.05)$ signaling market-oriented production (Vegetable is the 
cash crop usually grown for selling in the market). It is also reflected in the total land area under cultivation, where average land coverage of vegetable at household level has increased by 1.11 ropani (20 ropani $=1 \mathrm{ha}$ ) as shown in Table 4. Previously, this land was used for cultivating food crops (crops grown primarily for household consumption eg: maize, and millet) which experienced a drop in its average annual production and average land area by $10 \%$ and 0.83 ropani respectively. Their p-value smaller than 0.05 also signified the change was highly significant. The result coincides with one of the studies in Zambia, where road infrastructure has influenced farmers to cultivate high-value cash crop- cotton from maize (Dorward et al. 2004).

The growth in production escalates the quantity of supply to the market leading to the upsurge in the farm income (Boughton et al. 2007; Hong et al. 2011). In the study area, the average annual farm income has increased significantly by $84 \%(\mathrm{p}<0.05)$ as shown in Table 4. It is mainly due to the increase in revenue from selling vegetable and livestock products which upsurge farm income by $121 \%$ and $36 \%$ respectively. Surprisingly, the farm income generated from selling food crops has also increased significantly by $17 \%(\mathrm{p}<0.05)$ despite reduction in annual production by $10 \%$ and the average quantity sold to the market by $2 \%$. Similar association also existed between change in average quantity (93\%) and average annual income (121\%) of vegetable as the change in average annual income is tremendously larger than the quantity by $28 \%$. Such variations imply that farm production can't be considered as the sole factor responsible for farm income, other factors such as reduction in transaction cost and higher market prices could also have a positive effect on income. More than $90 \%$ of farmers during focus group discussion also confirmed that their farm income has increased because of reduction in transaction cost and improvement in their ability to decide price and profit of the crops. For food crops (Millet and Maize), they claimed that income has increased despite the average quantity of food crops sold to the market has remained more or less similar. Likewise, for cash crop (vegetables), the majority of farmers confirmed that they have been able to fetch higher prices due to the reduction in transport cost, quantity/quality loss and the number of intermediaries. On another hand, key informant interview with the retailer and wholesaler in major market centers at Phisling and Mugling admitted that the farmers from Chimmkeshwori and Hiklung supply high-quality vegetable directly without any intermediaries at the competitive 
price. They further confirmed that these farmers have been able to fetch higher prices as they bargain more aggressively with better knowledge of market price from various sources.

Table 4 Change in participation of farmers in output market through average annual production, farm income, quantity of crops sold to the market and average expenditure

\begin{tabular}{|c|c|c|c|c|c|}
\hline Variables & Unit & $\begin{array}{l}\text { Before } \\
\text { GGR }\end{array}$ & $\begin{array}{l}\text { After } \\
\text { GGR }\end{array}$ & $\begin{array}{l}\text { Change in } \\
\text { average value } \\
\text { before \& after } \\
\text { GGR }\end{array}$ & $\begin{array}{l}\text { t-value } \\
\text { (p-value) }\end{array}$ \\
\hline $\begin{array}{l}\text { Average annual production of } \\
\text { cash crop }\end{array}$ & $\mathrm{Kg} / \mathrm{HH}$ & 916 & 1765 & $93 \%$ & $\begin{array}{l}12.39 * * \\
(0.000)\end{array}$ \\
\hline $\begin{array}{l}\text { Average annual production of } \\
\text { food crop }\end{array}$ & $\mathrm{Kg} / \mathrm{HH}$ & 1167 & 1050 & $-10 \%$ & $\begin{array}{l}5.82 * * \\
(0.000)\end{array}$ \\
\hline $\begin{array}{l}\text { Average annual total crop } \\
\text { production }\end{array}$ & $\mathrm{Kg} / \mathrm{HH}$ & 2082 & 2815 & $35 \%$ & $\begin{array}{l}10.42^{* *} \\
(0.000)\end{array}$ \\
\hline $\begin{array}{l}\text { Average land area cultivated by } \\
\text { cash crop }\end{array}$ & ropani/HH & 1.25 & 2.37 & 1.11 & $\begin{array}{l}11.20^{* *} \\
(0.000)\end{array}$ \\
\hline $\begin{array}{l}\text { Average land area cultivated by } \\
\text { food crop }\end{array}$ & ropani/HH & 9.06 & 8.23 & -0.83 & $\begin{array}{l}6.15^{* *} \\
(0.000)\end{array}$ \\
\hline $\begin{array}{l}\text { Average annual income from } \\
\text { selling cash crops }\end{array}$ & $\mathrm{NPR} / \mathrm{HH}$ & 12513 & 27646 & $121 \%$ & $\begin{array}{l}11.06^{* *} \\
(0.000)\end{array}$ \\
\hline $\begin{array}{l}\text { Average annual income from } \\
\text { selling food crops }\end{array}$ & $\mathrm{NPR} / \mathrm{HH}$ & 3355 & 3942 & $17 \%$ & $\begin{array}{l}3.66 * * \\
(0.000)\end{array}$ \\
\hline $\begin{array}{l}\text { Average annual income from } \\
\text { selling livestock products }\end{array}$ & $\mathrm{NPR} / \mathrm{HH}$ & 5093 & 6903 & $36 \%$ & $\begin{array}{l}4.54 * * \\
(0.000)\end{array}$ \\
\hline Average annual total farm income & $\mathrm{NPR} / \mathrm{HH}$ & 20961 & 38490 & $84 \%$ & $\begin{array}{l}12.01^{* *} \\
(0.000)\end{array}$ \\
\hline $\begin{array}{l}\text { Average quantity of cash crop } \\
\text { sold to market }\end{array}$ & $\mathrm{Kg} / \mathrm{HH}$ & 780 & 1438 & $84 \%$ & $\begin{array}{l}11.70^{* *} \\
(0.000)\end{array}$ \\
\hline $\begin{array}{l}\text { Average quantity of food crop } \\
\text { sold to market }\end{array}$ & $\mathrm{Kg} / \mathrm{HH}$ & 179 & 175 & $-2 \%$ & $\begin{array}{l}0.53 * \\
(0.598)\end{array}$ \\
\hline Average annual food expenditure & NPR/HH & 28478 & 37204 & $31 \%$ & $\begin{array}{l}10.98^{* *} \\
(0.000)\end{array}$ \\
\hline $\begin{array}{l}\text { Average quantity of rice } \\
\text { purchased }\end{array}$ & $\begin{array}{l}\mathrm{Kg} / \mathrm{month} / \mathrm{H} \\
\mathrm{H}\end{array}$ & 18 & 29 & $64 \%$ & $\begin{array}{l}9.36^{* *} \\
(0.000)\end{array}$ \\
\hline $\begin{array}{l}\text { Average quantity of pulses } \\
\text { purchased }\end{array}$ & $\begin{array}{l}\mathrm{Kg} / \mathrm{month} / \mathrm{H} \\
\mathrm{H}\end{array}$ & 1.6 & 2.2 & $34 \%$ & $\begin{array}{l}7.49 * * \\
(0.000)\end{array}$ \\
\hline $\begin{array}{l}\text { Percent of HH consuming rice for } \\
\text { at least one time on a daily basis }\end{array}$ & $\begin{array}{l}\text { \% of } \mathrm{HH} \text {, } \\
\text { daily }\end{array}$ & $45 \%$ & $35 \%$ & $-24 \%$ & \\
\hline $\begin{array}{l}\text { Percent of } \mathrm{HH} \text { consuming rice for } \\
\text { two times on a daily basis }\end{array}$ & $\begin{array}{l}\% \text { of } \mathrm{HH} \text {, } \\
\text { daily }\end{array}$ & $20 \%$ & $50 \%$ & $143 \%$ & \\
\hline $\begin{array}{l}\text { Percent of } \mathrm{HH} \text { not consuming rice } \\
\text { on a daily basis }\end{array}$ & $\begin{array}{l}\% \text { of } \mathrm{HH} \text {, } \\
\text { daily }\end{array}$ & $35 \%$ & $16 \%$ & $-54 \%$ & \\
\hline $\begin{array}{l}\text { Percent of HH purchasing junk } \\
\text { food on a daily basis }\end{array}$ & $\begin{array}{l}\% \text { of } \mathrm{HH} \text {, } \\
\text { daily }\end{array}$ & $28 \%$ & $71 \%$ & $150 \%$ & \\
\hline $\begin{array}{l}\text { Percent of HH not purchasing any } \\
\text { junk food on a weekly basis }\end{array}$ & $\begin{array}{l}\% \text { of } \mathrm{HH} \text {, } \\
\text { weekly }\end{array}$ & $72 \%$ & $29 \%$ & $-59 \%$ & \\
\hline
\end{tabular}


Source: Household survey, 2016 (1 Hectare, ha = 20 ropani)

* \& **: Statistically significant at $10 \%$ and $5 \%$ respectively

When households' income increases, demand of goods and services also increases (Boughton et al. 2007), which is ultimately translated into higher household food and nonfood expenditure (Fan et al. 2013; Khandker et al. 2009). It reflects the standard process of agrarian and rural transformation from subsistence mode, where most inputs are provided, and most outputs are consumed internally, to a market engagement mode, with inputs and products increasingly purchased and sold off the farm (Staatz 1994). Similarly, before the installation of GGR in the study site, farmers used to rely on their farm product of food crops and whatever was produced, they used to consume. However, the produced food crop was sufficient for 6 to 9 months resulting in the food deficit and food insecurity for the remaining 3 to 4 months. The fastest connection with the markets and increase in income has helped farmers to address food deficit problem and actively participate in market purchasing foods to fulfill their food needs for the whole year. Thus, average annual food expenditure has significantly increased by $31 \%$ ( $\mathrm{p}<$ 0.05) as shown in Table 4. Especially, farmers have spent their income on purchasing rice and pulses from the market. The average quantities of rice and pulse purchased from the market on a monthly basis have upsurged by $64 \%$ and $34 \%$ respectively. Particularly, the number of households consuming rice two times per day on a daily basis has increased by a staggering $143 \%$ whereas families that do not consume rice on a daily basis has reduced by $54 \%$. Surprisingly, the purchase of ready-made processed food such as noodles, biscuits, and cookies has escalated significantly among children. The traditional way to consume food two times a day (morning and evening) or consuming locally made food from maize for children has changed entirely. Prior GGR, only 33 households (29\%) used to buy such processed food occasionally (once or twice a month) when farmers travel to the nearby markets in Phisling, Mugling, and Hetauda located outside the village as illustrated in Table 4. Now 80 households (70\%) consume processed foods such as biscuits and noodles as mid-day meals on a daily basis purchasing from the local grocery store opened after the installation of GGR in all three villages. 


\section{Participation in the input market}

Transportation accessibility enhances the activity in the input market as well (Årethun and Bhatta 2012; Stifel and Minten 2008). Lower transaction and transportation cost reduces the cost of farm input further motivating farmers to engage in commercial farming (Walle and $\mathrm{Mu}$ 2011). However, in the study sites, the participation in the input market was relatively low as shown in Table 5 . The average quantity of chemical fertilizers purchased by a HH increased by just $4 \mathrm{~kg}$, which is not a remarkable change. It is because farmers were mainly dependent on organic manure from their cattle from the beginning. Before GGR, the average quantity of cattle manure used by an individual household was $1950 \mathrm{~kg}$, which increased to $2185 \mathrm{~kg}$ after GGR. The pvalue of 0.120 also signified that change is not significant implying that usage has remained more or less similar. Almost $72 \%$ of households (82) owned an average of 7 cattle, relying on organic manure for farming. After GGR, only 78\% household (88) opted cattle farming holding 8 animals on average as presented in Table 5. It did not increase their participation in the input market as farmers preferred to breed their cattle locally inside the village and were buying these cattle very rarely from nearby market located in Mugling and Hetauda. More than 90\% respondents during FGD also confirmed that there was no change in their number of cattle with the use of GGR, as they have owned livestock prior installation of GGR for household consumption and organic manure. This situation resonates with the common practice of mix farming prevalent in other rural parts of Nepal rearing cattle for household consumption and organic fertilizer (Devkota et al. 2011; Maraseni 2008; Pradhanang et al. 2015). Interestingly, the use of organic manure has added credence to vegetable's attributes regarding taste, freshness, traceability quality, and appearance thereby, creating enormous demand and fetching higher prices in nearby markets. For instance, retailers and wholesaler in Mugling, Phisling, and Khaireni reported that the end consumer from surrounding area preferred to buy vegetables from Hiklung and Chimkeshwori at higher prices due to its taste and higher quality.

There is no any significant change in the purchase of other input such as seeds, modern tools as shown in Table 5. More than $58 \%$ of HHs still use vegetable seeds produced locally and only $42 \%$ HHs (28) purchase vegetable seeds from the market. The annual average amount spent by household is low as NPR 107 (100 NPR = 1 USD) since they are buying from the market only when seeds produce locally couldn't generate sufficient quantity for the available farmland. Likewise, farmers produce seed of food crops within the village as only $31 \mathrm{HHs}$ reported having bought 
from the nearby market in Phisling, Mugling, and Hetauda after installation of GGR. The respective p-values of 0.057 and 0.829 also indicate the change is not significant. For irrigation, farmers rely mostly on rainwater (during rainy season) and groundwater (during winter season). Regarding other farming technologies, farmers continue to use the traditional plough and oxen method, as it is cheap and readily available in the village. Purchase and use of modern tools and technologies (hand tractors) were almost absent in all three sites because they would require higher cost given the majority of the land parcels were small and highly gradient.

Table 5 Change in farmer's participation in input market through purchase of fertilizer, livestock, and seed

\begin{tabular}{|c|c|c|c|c|c|}
\hline Variables & Unit & $\begin{array}{l}\text { Before } \\
\text { GGR }\end{array}$ & $\begin{array}{l}\text { After } \\
\text { GGR }\end{array}$ & $\begin{array}{l}\text { Change in } \\
\text { average value } \\
\text { before and after } \\
\text { GGR }\end{array}$ & $\begin{array}{l}\text { t-value } \\
\text { (p- } \\
\text { value) }\end{array}$ \\
\hline $\begin{array}{l}\text { Average quantity of chemical } \\
\text { fertilizer purchased annually }\end{array}$ & $\mathrm{kg} / \mathrm{HH} / \mathrm{yr}$ & 48 & 54 & $12 \%$ & $\begin{array}{l}2.18^{* *} \\
(0.031)\end{array}$ \\
\hline $\begin{array}{l}\text { Average quantity of organic } \\
\text { fertilizer produced annually }\end{array}$ & $\mathrm{kg} / \mathrm{HH} / \mathrm{yr}$ & 1948 & 2185 & $12 \%$ & $\begin{array}{l}1.56 \\
(0.120)\end{array}$ \\
\hline $\begin{array}{l}\text { Percent of HHs with at least } \\
\text { one cattle }\end{array}$ & $\%$ & $73 \%$ & $78 \%$ & $5 \%$ & \\
\hline $\begin{array}{l}\text { Average number of livestock } \\
\text { (hen cow, buffalo and goat) } \\
\text { owned }\end{array}$ & Number/HH & 6 & 8 & $28 \%$ & \\
\hline $\begin{array}{l}\text { Average amount spent on } \\
\text { vegetable seeds }\end{array}$ & NPR/ HH/yr & 69 & 107 & $55 \%$ & $\begin{array}{l}1.92^{*} \\
(0.057)\end{array}$ \\
\hline $\begin{array}{l}\text { Percent of HHs purchasing } \\
\text { vegetable seeds from the } \\
\text { market }\end{array}$ & $\%$ & $22 \%$ & $42 \%$ & $88 \%$ & \\
\hline $\begin{array}{l}\text { Average amount spent on food } \\
\text { crop seeds }\end{array}$ & NPR/HH/yr & 25 & 43 & $69 \%$ & $\begin{array}{l}0.21 \\
(0.829)\end{array}$ \\
\hline $\begin{array}{l}\% \text { of HHS purchasing cash } \\
\text { crop seeds }\end{array}$ & $\%$ & $8 \%$ & $19 \%$ & $10 \%$ & \\
\hline
\end{tabular}

Source: Household survey, 2016

* \&**: Statistically significant at $10 \%$ and $5 \%$

\section{Conclusion}

GGR has ensured better transportation and territorial accessibility to market for farmers residing in high hills in Nepal, where the majority of people practice subsistence farming living in abject poverty constrained by harsh topography, low production, and inadequate infrastructure. The installation of GGR has favored smallholder farmers concerning the price negotiation process. 
With the significant reduction in average travel time from uphill to the final market by 57\% ( $<<$ 0.05), the farmers were able to transport the high-quality product to buyers throughout the year. Likewise, any time transport of high-quality farm product has established a direct connection with both small-scale and large-scale buyers. Interestingly, farmers were even forming a market management committee to consolidate and supply a sizable volume of farm products to large buyers. It further eliminated the role of intermediaries who previously used to accumulate and buy agriculture produce at farm gate at a comparatively lower price. Consequently, farmers have acquired the immense power to dictate the final price capturing the larger share in the profit.

The per unit transaction cost per household has also reduced significantly after use of GGR. Notably, the high transportation cost from uphill to the end market has markedly reduced by $43 \%(p<0.05)$. Likewise, quick direct access to the market has diminished post-harvest transportation loss further enhancing the competitiveness of the product in the market. More importantly, extensive use of mobile phones and radio has also lowered down the cost of searching for information concerning market price and buyers. All these factors have created a favorable environment to conduct the transaction for smallholder farmers further strengthening their position in the price negotiation process and capturing the larger share in the final selling price ultimately increasing their income.

Farmers are capable of involving in the output market regardless of their small farm size and lower farm production. Particularly, the average annual production and sale of high-value crops (vegetable) per household has increased significantly by $93 \%(\mathrm{p}<0.05)$ and $84 \%(\mathrm{p}<0.05)$. On the contrary, the average annual food crop production and the quantity of food crop sold to the market have reduced by $10 \%$ and $2 \%$. Surprisingly, despite the reduction in production, the farm income from food production has increased by $17 \%(\mathrm{p}<0.05)$ like income from cash crop and livestock product ultimately increasing average annual farm income further implying that transaction cost and negotiation power has also contributed to farm income. Subsequently, farmers also experienced a rise in average yearly food expenditure by $31 \%$ and were able to purchase varieties of food comprising rice, pulses and processed food fulfilling the food need for the whole year, which was not possible cultivating food crop before GGR.

Unlike the output market, the participation of farmers in the input market has remained low. Not a significant involvement was found in chemical fertilizer market as the average annual 
quantity of chemical fertilizer purchased increased by just $12 \%$. It was because people continued to use the organic manure from their cattle even after the installation of GGR. Similarly, the farmers tend to produce local seeds and maintain the usage of plough and oxen technology given its easy availability and applicability in highly elevated farmlands.

Thus, GGR could be one of the suitable means of the transportation system for high hills and mountain given its potential in connecting farmers with the market and improving farm income of smallholder farmers. However, impact alone is not adequate to justify its appropriateness. Other factors also attribute the suitability of the technology which this study did not consider. One of the crucial aspects is cost-effectiveness. Although production and operation cost of GGR is lower than the road infrastructure, it is also essential to look if it is feasible to install GGR to benefit a small community of 80-90 families residing in high hills. The paper didn't explain whether the benefits/impacts acquired by small community exceeded the installation and operation cost of GGR. Secondly, the continued operation also determine the feasibility of the technology. This paper didn't explore whether the donor agency/ government agency is still financing the operation cost or community has taken its ownership for the management and operation. The latter would ensure the longevity and sustainability of the project. Lastly, the paper hasn't explored other possibilities to improve/upgrade GGR (electric or biogas powered) or the use of other advanced technologies such as Zipline. The modern or upgraded technology might have more significant impacts at the same or reduced installation and operation cost. Hence, there are much room to explore and many ideas to continue this research to identify that this technology is suitable and effective. Such research would help to produce reliable evidence and answer that GGR is a useful technology and should be promoted in other mountain regions of Nepal and elsewhere. 


\section{Acknowledgments:}

We want to extend our sincerest thanks to Global Center for Food System Innovation at Michigan State University for funding this research. We are grateful to the TERI School of Advanced Studies for facilitating the study. Our sincere gratitude to Practical Action Nepal for providing access to the study areas. We extend our appreciation to the local communities and all the respondents in the study areas for their enthusiasm in sharing their knowledge and experiences on GGR.

\section{Conflict of Interest:}

On behalf of all authors, the corresponding author states that there is no conflict of interest.

\section{Authors' Contribution:}

D. KC:

Methodology Design, Data Collection and Field Survey, Literature Survey, Data

Analysis, and Manuscript Writing

T. Maraseni:

Analysis, Manuscript Writing, and Editing

C. Jamir:

Methodology Design, Analysis and Content Planning

R. Thapa Magar:

Methodology Design, Literature Survey, and Finalization of Questionnaires

F. Tuladhar:

Literature survey, Analysis, and Mapping 


\section{Reference}

ADB: Proposed Loan for Additional Financing Nepal- Community-Managed Irrigated Agriculture Sector Project. (2014)

ADB: Country Poverty Analysis: Nepal. Asian Development Bank, Kathmandu, Nepal (2017)

Ahmed, R., Hossain, M.: Developmental impact of rural infrastructure in Bangladesh. International Food Policy Research Institute, Dhaka (1990)

Altheide, D.L.: Reflections: Ethnographic content analysis. Qual. Sociol. 10, 65-77 (1987). doi:https://doi.org/10.1007/BF00988269

Anderson, K., Masters, W.A. eds: Distortions to Agricultural Incentives in Africa. The World Bank, Washington DC (2009)

Årethun, T., Bhatta, B.P.: Contribution of Rural Roads to Access to- and Participation in Markets: Theory and Results from Northern Ethiopia. J. Transp. Technol. 02, 165-174 (2012). doi:10.4236/jtts.2012.22018

Arias, P., Morrison, J., Hallam, D., Krivonos, E.: Smallholder integration in changing food markets. FAO (2013)

Baker, J.L.: Evaluating the impact of development projects on poverty: A handbook for practitioners. The World Bank (2000)

Baral, S.D.: Gravity Ropeway: Could be a reliable source of transport the goods and services in Hills and Mountainous region of Nepal. 6th International Symposium "Networks for Mobility". , Stuttgart, Germany (2012)

Barrett, C.B.: Smallholder Market Participation: Concepts and Evidence from Eastern and Southern Africa. Food Policy. 33, 299-317 (2008). doi:10.1016/j.foodpol.2007.10.005

Basnett, Y., Henley, G., Howell, J., Jones, H., Lemma, A., Pandey, P.R.: Structural Economic Transfermation in Nepal. Department for International Development, Kathmandu, Nepal (2014)

Boughton, D., Tschirley, D., Cunguara, B., Mather, D., Barrett, C.B., Benfica, R., Abdula, D.: Market Participation by Rural Households in a Low-Income Country- An Asset-Based Approach Applied to Mozambique. Faith Econ. 50, 64-101 (2007)

Bwalya, R., Mugisha, J., Hyuha, T.: Transaction costs and smallholder household access to maize markets in Zambia. J. Dev. Agric. Econ. 5, 328-336 (2013). doi:10.5897/JDAE12.134

Cuevas, A.C.: Transaction Costs of Exchange in Agriculture: A Survey. Asian J. Agric. Dev. 11, (2014)

Devkota, B., Dudycha, D., Andrey, J.: Planning for non-motorized travel in rural Nepal: a role for geographic information systems. J. Transp. Geogr. 24, 282-291 (2012). doi:10.1016/j.jtrangeo.2012.03.007

Devkota, R.P., Bajracharya, B., Maraseni, T.N., Cockfield, G., Upadhyay, B.P.: The perception of Nepal's Tharu community in regard to climate change and its impacts on their livelihoods. Int. J. Environ. Stud. 68, 937946 (2011). doi:10.1080/00207233.2011.587282

Dhakal, A., Cockfield, G., Maraseni, T.N.: Evolution of agroforestry based farming systems: a study of Dhanusha District, Nepal. Agrofor. Syst. 86, 17-33 (2012). doi:10.1007/s10457-012-9504-x 
DOLIDAR: Technical guidelines for gravity goods ropeways. DoLIDAR and Practical Action, Kathmandu (2010)

Dorosh, P., Wang, H.G., You, L., Schmidt, E.: Crop production and road connectivity in Sub-Saharan Africa: a spatial analysis. World Bank, Washington DC, USA (2010)

Dorward, A., Kydd, J., Morrison, J., Urey, I.: A policy agenda for pro-poor agricultural growth. World Dev. 32, 7389 (2004). doi:https://doi.org/10.1016/j.worlddev.2003.06.012

Fafchamps, M., Hill, R.: Selling at the farm-gate or traveling to market. Am. J. Agric. Econ. 87, 717-734 (2005). doi:10.1111/j.1467-8276.2005.00758.x

Fan, S., Halsema, B., Keyzer, M.: From Subsistence to Profit: Transforming Smallholder Farms. IFPRI, Washington DC (2013)

FAO: The future of food and agriculture: trends and challenges. Food and Agriculture Organization, Rome (2017)

Ferris, S., Robbins, P., Best, R., Seville, D., Buxton, A., Shriver, J., Wei, E.: Linking smallholder farmers to markets and the implications for extension and advisory services. USAID, Washington DC (2014)

Gabre-Madhin, E.Z.: Of markets and middlemen: Transforming agricultural markets in Ethiopia. International Food Policy Research Institute, Washington DC (2001)

Hong, J., Chu, Z., Wang, Q.: Transport infrastructure and regional economic growth: evidence from China. Transportation. 38, 737-752 (2011). doi:10.1007/s11116-011-9349-6

Hunzai, K., Gerlitz, J.Y., Hoermann, B.: Understanding mountain poverty in the Hindu Kush-Himalayas. International Centre for Integrated Mountain Development, Kathmandu (2011)

IFAD: Rural poverty report- New realities, new challenges: new opportunities for tomorrow's generation. IFAD, Rome (2011)

Jacoby, H.G., Minten, B.: On measuring the benefits of lower transport costs. J. Dev. Econ. 89, 28-38 (2009)

Janvry, A. de, Fafchamps, M., Sadoulet, E.: Peasant Household Behavior With Missing Markets: Some Paradoxes Explained. Econ. J. 1400-1417 (1991). doi:10.2307/2234892

Jayne, T.S., Mason, N.M., Myers, R.J., Ferris, J.N., Mather, D., Sitko, N., Beaver, M., Lenski, N., Chapoto, A., Boughton, D.: Patterns and Trends in Food Staples Markets in Eastern and Southern Africa: Toward the Identification of Priority Investments and Strategies for Developing Markets and Promoting Smallholder Productivity Growth. Michigan State University, Department of Agricultural, Food, and Resource Economics, Michigan (2010)

Jin, H., Stoeckl, N., Zhang-yue, Z.: Poverty in Mountainous Areas in Rural China: Issues and Suggestions to Encourage Sustainable Development. Presented at the Managing Natural Resources in Australia, Sydney (2006)

Jordaan, H., Grové, B., Backeberg, G.R.: Conceptual framework for value chain analysis for poverty alleviation among smallholder farmers. Agrekon. 53, 1-25 (2014). doi:10.1080/03031853.2014.887903

Karki, R., Karki, B.: An Assessment of Market Oriented Production and Agri-business by the Smallholders: Some Approaches and Evidences from Rural Hills of Nepal. Rural Reconstruction Nepal, Kathmandu (2011) 
KC, L.: Gravity goods ropeway an alternative sustainable solution for rural transportation with out hampering to the natural environment and climate: A case study from Janagaun village. In: IOP Conference Series: Earth and Environmental Science. pp. 1-2. IOP Publshing Limited, Copenhagen (2009)

Key, N., Sadoulet, E., Janvry, A.D.: Transactions costs and agricultural household supply response. Am. J. Agric. Econ. 82, 245-259 (2000)

Khandker, S., Bakht, Z., Koolwal, G.: The poverty impact of rural roads: Evidence from Bangladesh. Econ. Dev. Cult. Change. 57, 685-722 (2009). doi:10.1086/598765

Kiprono, P., Matsumoto, T.: Roads and Farming: The Effect of Infrastructure Improvement on Agricultural Input Use, Farm Productivity and Market Participation in Kenya. Presented at the CSAE Conference 2014: Economic Development in Africa, T , Oxford March 23 (2014)

Leeuw, F., Vaessen, J.: Impact Evaluations and Development: Guidance on Impact Evaluation. World Bank, Washington DC (2009)

Lowder, S.K., Skoet, J., Raney, T.: The Number, Size, and Distribution of Farms, Smallholder Farms, and Family Farms Worldwide. World Dev. 87, 16-29 (2016). doi:10.1016/j.worlddev.2015.10.041

Magar, R.T.: Gravity goods ropeways: a sustainable solution for rural transportation in hilly and mountainous regions of nepal,

https://scholarsbank.uoregon.edu/xmlui/bitstream/handle/1794/20424/ThapaMagar_oregon_0171N_11478.pd f?sequence $=1$, (2016)

Maraseni, T.N.: Selection of Non-timber Forest Species for Community and Private Plantations in the High and Low Altitude Areas of Makawanpur District, Nepal. Small-Scale For. 7, 151-161 (2008). doi:10.1007/s11842-008-9047-1

Maraseni, T.N., Shivakoti, G.P., Cockfield, G., Apan, A.: Nepalese non-timber forest products: An analysis of the equitability of profit distribution across a supply chain to India. Small-Scale For. Econ. Manag. Policy. 5, 191-206 (2006). doi:10.1007/s11842-006-0010-8

Markelova, H., Mwangi, E.: Collective Action for Smallholder Market Access- Evidence and Implications for Africa. Rev. Policy Res. 27, 621-640 (2010). doi:https://doi.org/10.1111/j.1541-1338.2010.00462.x

Minten, B.: Infrastructure, market access, and agricultural prices: evidence from Madagascar. International Food Policy Research Institute, Washington DC (1999)

Mohanty, S.K., Rasul, G., Mahapatra, B., Choudhury, D., Tuladhar, S., Holmgren, E.V.: Multidimensional Poverty in Mountainous Regions: Shan and Chin in Myanmar. Soc. Indic. Res. 138, 23-44 (2018). doi:10.1007/s11205-017-1662-9

Morgan, D.L.: Qualitative Content Analysis: A Guide to Paths not Taken. Qual. Health Res. 3, 112-121 (1993). doi:10.1177/104973239300300107

Neven, D., Odera, M.M., Reardon, T., Wang, H.: Kenyan Supermarkets, Emerging Middle-Class Horticultural Farmers, and Employment Impacts on the Rural Poor. World Dev. 37, 1802-1811 (2009). doi:10.1016/j.worlddev.2008.08.026 
NPC: Periodic Plans: National Planning Commission. National Planning commission, Kathmandu (2016)

Papola, T.S.: Poverty in mountain areas of the Hindu Kush Himalayas: some basic issues in measurement, diagnosis, and alleviation. International Centre for Integrated Mountain Development, Kathmandu (2002)

Pingali, P., Khwaja, Y., Meijer, M.: Commercializing small farms: Reducing transaction costs. FAO, Rome (2005)

Pokhrel, D.M.: Comparison of farm production and marketing cost and benefit among selected vegetable pockets in Nepal. J. Agric. Environ. 11, 10-25 (2010)

Pokhrel, D.M., Thapa, G.B.: Are marketing intermediaries exploiting mountain farmers in Nepal? A study based on market price, marketing margin and income distribution analyses. Agric. Syst. 94, 151-164 (2007). doi:10.1016/j.agsy.2006.08.004

Pradhanang, U., Pradhanang, S., Sthapit, A., Krakauer, N., Jha, A., Lakhankar, T.: National Livestock Policy of Nepal: Needs and Opportunities. Agriculture. 5, 103-131 (2015). doi:10.3390/agriculture5010103

Staatz, J.M.: The strategic role of food and agricultural systems in fighting hunger through fostering sustainable economic growth. Department of Agricultural Economics, Michigan State University, Michigan (1994)

Stifel, D., Minten, B.: Isolation and agricultural productivity. Agric. Econ. 39, 1-15 (2008). doi:10.1111/j.15740862.2008.00310.x

Suvedi, M., Vander Stoep, G.: Improving the Monitoring and Evaluation of Agricultural Extension Programs. (2016)

Thünen, J.H. von, Wartenberg, C.M., Hall, P.: Isolated State. Pergamon Press, Oxford (1966)

United Nations: Report of the Inter-Agency and Expert Group on Sustainable Development Goal Indicators. UniIted Nations Economic and Social Council, New York (2016)

Walle, D.P.V. de, Mu, R.: Rural roads and poor area development in Vietnam. J. Dev. Stud. 47, 709-734 (2011). doi:https://doi.org/10.1080/00220381003599436

Wickramasinghe, U., Weinberger, K.: Smallholder Market Participation and Production Specialization Evolution of thinking, issues and policies. United Nations Economic and Social Commission for Asia and the Pacific, Bogor, Indonesia (2013)

World Bank: Poverty and Shared Prosperity 2016:Taking on Inequality. World Bank, Washington DC, USA (2016)

Diwakar KC is a Ph.D. Candidate at Griffith University, Australia. He has worked as Researcher and Practitioner in various projects on poverty reduction in Nepal and abroad. His research focuses in market access and value chain development for poor people.

Tek Maraseni is Associate Professor at University of Southern Queensland, Australia. He is currently conducting various research projects on forestry, value chain, transportation access, 
natural resource management in 10 different countries. He has published over 130 publications including four books.

Chubamenla Jamir is Assistant Professor at Teri School of Advanced Studies, India. Her research interests include market access, value chain development, air pollution and climate change impacts on agricultural crop yield and socio-economic condition of poor people.

Ritendra Thapa Magar earned a Master's in International Studies from University of Oregon, USA. His interest lies in solving real-world problems related to transportation challenges faced by mountain communities through the advancement of low cost and environmentally friendly technologies.

Florencia Tuladhar has worked as a Lecture at Kathmandu University, Nepal. She has also worked as GIS expert with Japan Science and Technology Agency on building database for earthquake-affected areas in Nepal. Her research interests are spatial database management, cartography, and geoinformatics. 